\title{
Presentació del monogràfic. «Els valencians davant les urnes: partits polítics, mitjans de comunicació i ciutadans davant els processos electorals de 2019»
}

\author{
Coordinado por \\ Guillermo López García \\ UNIVERSITAT DE VALÈNCIA
}

\section{INTRODUCCIÓ: CAMPANYES ESCINDIDES I RESULTATS CONTINUISTES EN EL CICLE ELECTORAL DE 2019}

Tant en l'àmbit autonòmic com en el local, la legislatura 2015-2019 va encarnar el canvi polític al País Valencià. Després de la llarga hegemonia del Partit Popular, que va governar durant vint anys a la Generalitat Valenciana i fins i tot més temps a ciutats com València, els comicis autonòmics i municipals de 2015 van atorgar un clar triomf als partits d'esquerres. La combinació de PSPV, Compromís, Podem i Esquerra Unida va assolir el $54 \%$ dels vots i 55 dels 99 escons, una majoria absoluta clara, tot i que EUPV no va obtindre representació en les Corts Valencianes, i per tant els sufragis dirigits a aquesta opció política —un $4 \%$ del total- no es van transformar en escons. A més, l'esquerra va recuperar l'alcaldia de les tres capitals de província i es va fer amb el poder als principals nuclis poblacionals i amb el control de la Diputació de València.

Amb aquest punt de partida, i després d'una legislatura en què el Consell no va cometre errors significatius -encara que tampoc grans realitzacions, en part per les dificultats financeres que arrossega la Generalitat des de fa més d'una dècada pel deute contret i l'insuficient finançament autonòmic-, i en què la relació entre els socis de coalició d'esquerres no va generar els problemes que s'havien augurat inicialment, les eleccions ens abocaven -en principi-a una situació de continuïtat. Així ho afirmaven quasi totes les enquestes, que van pronosticar la revalidació de la majoria absoluta en les Corts Valencianes i en la majoria dels feus obtinguts per l'esquerra l'any 2015.

No obstant això, aquestes previsions van quedar parcialment en suspens per l'avançament electoral decidit pel president de la Generalitat Valenciana, Ximo Puig, qui va aprofitar la convocatòria d'eleccions generals per a fer coincidir aquests comicis amb els autonòmics. Aquest fet ens va conduir a una situació insòlita en tota la història democràtica del País Valencià: per primera vegada des de la instauració de l'autonomia, les eleccions autonòmiques no coincidirien amb les municipals, encara que només fora per un mes de diferència. Puig va presentar aquesta decisió com un símbol de l'aprofundiment de l'autonomia i la especificitat de les institucions valencianes, però la veritat és que el seu 
propòsit era fonamentalment electoral: maximitzar l'efecte d'arrossegament del vot cap als socialistes en unes eleccions autonòmiques que coincidien amb els comicis nacionals.

De fet, la campanya electoral va estar molt condicionada per les eleccions generals, l'agenda de campanya i la presència dels líders dels grans partits al País Valencià. Els temes i els debats d'àmbit valencià van quedar clarament en un segon pla. La votació, en canvi, sí que va mostrar diferències palpables en la intenció de vot a uns partits o altres, amb un vot dual particularment intens en el cas de Compromís —molt major en les autonòmiques que en les generals-, però també present en el cas d'Unides Podem —en sentit invers, amb més vots en les eleccions generals que en les autonòmiques$i$, en menor mesura, en els casos del PSPV i de Vox. Si considerem ambdues votacions globalment, els resultats de les eleccions generals van resultar més favorables a les forces de la dreta, que van empatar amb l'esquerra amb el $48 \%$ dels vots, mentre cedien un $2 \%$ en les autonòmiques ( $48 \%$ de l'esquerra enfront del $46 \%$ de la dreta). En aquest $2 \%$ de diferència de la dreta resideix la victòria per la mínima del Botànic, que d'aquesta manera va aconseguir revalidar la seua majoria, però es va deixar quatre escons pel camí (va baixar de 55 a 51) i va perdre un major percentatge de vots (del $54 \%$ el 2015 al $48 \%$ el 2019).

Un mes després, al maig de 2019, es van celebrar segons el previst les eleccions municipals a tota Espanya, així com les eleccions al parlament europeu. En aquesta ocasió, atesa la naturalesa dels comicis locals i el desinterés de molts votants per les eleccions europees -que tradicionalment obtenen un percentatge de participació molt inferior al d'altres votacions-, el procés electoral es va veure molt menys condicionat per l'agenda espanyola i, per contra, va derivar notablement de les dinàmiques locals. Quant als resultats, es va consolidar la tendència iniciada el $2015 \mathrm{i}$ el vot es va concentrar entorn dels partits que ostentaven l'alcaldia a la major part dels municipis i, per descomptat, als de major població. Fet que implicava que l'esquerra continuaria controlant els municipis més importants, a excepció d'Alacant capital, que havia sigut recuperada pel PP el 2018 després d'una moció de censura en què un trànsfuga de Podem va recolzar el candidat popular, Luis Barcala. L'incident d'Alacant i el canvi de majories a la Diputació de 
Castelló — també regentada des d'ara pel PSPV— van ser les dues principals variacions respecte de les eleccions de 2015.

Aquesta llarga successió de campanyes electorals, que pot considerar-se quasi com una única campanya composta per diversos comicis, sempre entrecreuada amb altres eleccions d'àmbit nacional, constitueix l'objecte d'estudi del present monogràfic. Busquem posar de manifest les principals línies de força d'ambdues campanyes electorals (autonòmiques i municipals): les polítiques — que acabem d'esbossar-, però també les mediàtiques, perquè aquestes eleccions es van donar en un context on l'ecosistema comunicatiu valencià va evolucionar singularment respecte del de 2015; si més no, en dos sentits.

D'una banda, la tornada de la radiotelevisió pública, À Punt. Si l'any 2015 la recuperació del servei públic de ràdio i televisió autonòmiques va ser un dels temes recurrents de debat en la campanya, quatre anys després, el 2019, la seua participació efectiva va redimensionar l'estructuració d'aquesta campanya a efectes mediàtics. D'altra banda, el 2019 l'activitat de les xarxes socials i la seua incidència pràctica com a vehicle de tota mena d'informacions i opinions ha sigut sens dubte molt significativa, en un context de polarització política cada vegada més accentuada. Aquest context es caracteritza, a més, per la presència de partits d'extrema dreta, com ara Vox, amb representació parlamentària, així com per la difusió de tota mena d'estratègies de desinformació que busquen condicionar el vot basant-se en premisses falses o tergiversades. Tindrem ocasió d'analitzar totes aquestes línies de força de sengles campanyes en els nou articles que componen aquest monogràfic. 


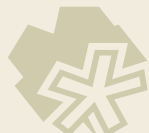

